\title{
PENGARUH KEBUTUHAN BERPRESTASI DAN KARAKTERISTIK PERSONAL TERHADAP KINERJA USAHA WIRAUSAHA WANITA (Survey pada Petani Tanaman Obat Keluarga (TOGA) di Kecamatan Jumantono Kabupaten Karanganyar)
}

\author{
Setyaningsih $\mathrm{SU}^{1}$, Edi Wibowo ${ }^{2}$ \\ ${ }^{1,2)}$ Fakultas Ekonomi Universitas Slamet Riyadi Surakarta \\ e-mail: u.setya@yahoo.co.id ${ }^{1}$; ediwibowo58@gmail.com²
}

\begin{abstract}
This study aims to analyze the effect of the needs of achievement and personal characteristics (education, age, experience, training) on business performance. This research is census research, using 63 respondents of women entrepreneurs to Toga farmers in Jumantono District, Karanganyar Regency. Data analysis technique using binary logistic regression analysis. The conclusions from the results of this study indicate that the needs of achievement and personal characteristics of business experience have a significant effect on business performance, while the variables of education, age, and entrepreneurship training have no significant effect on business performance. Based on the results of this study, the odds/probabilities of the performance of women's entrepreneurial business in Toga farmers in Jumantono District, Karanganyar Regency can be predicted by the needs of achievement and business experience. The implication of this finding is that to achieve high business performance, Toga farmers in Jumantono District, Karanganyar Regency need to increase their needs for achievement and business experience.

Keywords: needs of achievement, education, age, experience, training, business performance
\end{abstract}

\section{PENDAHULUAN}

Dalam kehidupan berbangsa

dan bernegara, masalah

kewirausahaan (entrepreneurship) merupakan faktor penting dalam perekonomian suatu bangsa yang sedang membangun. Kemajuan dan kemunduruan suatu bangsa sangat ditentukan oleh keberadaan dan peran dari kelompok wirausahawan (Windi Astuti \& Murwatiningsih, 2016). Usaha kecil sekarang ini makin penting, hampir setipa bulan ada yang mendirikan usaha kecil, tetapi lingkungan usaha sekarang ini semakin rumit. Perusahan-perusahaan kecil sulit mengembangkan kemampuan manajerialnya yang diperlukan untuk bertahan dilingkungan yang penuh persaingan (Daft, 2010). Amirullah dan Imam Hardjianto (2005) menyatakan jika bangsa tidak memiliki modal manusia sebagai entrepreneur sangat sulit diharapkan adanya sebuah kemajuan dari bangsa ini.

Peran ibu rumah tangga merupakan komponen bangsa yang dapat diberdayakan untuk peningkatan kesejahteraan keluarga. Kondisi di lapangan menunjukkan bahwa selama ini pemanfaatan dan pengelolaan sumberdaya perdesaan sebagian besar dilakukan oleh laki- 


\section{Research Fair Unisri 2019 \\ Vol 4, Number 1, Januari 2020}

laki, mulai dari kegiatan di bidang pertanian, peternakan, industri kecil dan menengah, koperasi, dan kegiatan lain yang sifatnya kegiatan ekonomi. Padahal perempuan sebagai anggota masyarakat juga mempunyai hak untuk ikut serta dalam pemanfaatan dan pengelolaan sumberdaya perdesaan, meskipun kemungkinan peran perempuan tidak sebesar peran laki-laki(Diah Nurdiwaty dkk, 2017: 21).

Salah satu program yang dapat dilaksanakan oleh perempuan dalam upaya peningkatan kesejahteraan keluarga, khususnya di bidang pangan adalah program penanaman dan pemanfaatan Tanaman Obat Keluarga (TOGA). Program ini sekaligus menyikapi menurunnya daya beli masyarakat akibat harga obat yang semakin mahal, sehingga secara tidak langsung berdampak pada menurunnya derajat kesehatan masyarakat. TOGA adalah tanaman hasil budidaya rumahan yang berkhasiat sebagai obat. Penanaman TOGA dapat di pot atau di lahan sekitar rumah, dan jika lahan yang ditanami cukup luas maka sebagian hasil panen dapat dijual dan menambah pendapatan keluarga. Adapun pemanfaatan TOGA selain sebagai obat, juga dapat dimanfaatkan untuk: (1) penambah gizi keluarga (pepaya, timun, bayam), (2) bumbu atau rempah-rempah masakan (kunyit, kencur, jahe, serai, daun salam), (3) menambah keindahan (mawar, melati, bunga matahari, kembang sepatu, tapak dara, kumis kucing) (Diah Nurdiwaty dkk, 2017: 21).

Desa Ngunut Kecamatan Jumantono Kabupaten Karanganyar adalah salah satu percontohan Kampung TOGA. Sejalan dengan hal tersebut, Tim Evaluasi Penilaian Lomba Hari Kesatuan Gerak (HKG) PKK Provinsi Jawa Tengah meninjau langsung kondisi hasil toga (Tanaman Obat Keluarga) di Kabupaten Karanganyar yang diwakili Desa Ngunut, Kecamatan Jumantono. Pada tahun 2016 Desa Ngunut Jumantono berhasil menjadi Juara I dengan kategori Pemanfaatan HasilTanaman Obat Keluarga (TOGA) Tingkat Nasional.

Menurut Siti Komsiah Juliyatmono, masyarakat Desa Ngunut mempunyai gerakan menanam toga di pekarangan dan di kebun rumah mereka. Warga desa juga mempunyai pastisipasi dalam membangun desa wisata toga, terdapat tanaman toga seperti jahe, kunir, temu lawak dan dewa. Dalam mengembangkan hasill toga, juga mendapatkan pendampingan dari Balai Besar Penelitian dan Pengembangan Tanaman Obat dan Obat Tradisional (B2P2TOOT) Tawangmangu dan Dinas Pertanian Tanaman Pangan Perkebunan dan 
Kehutanan Kabupaten Karanganyar (http://www.karanganyarkab.go.id).

Fenomena pemberdayaan petani wanita di Desa Ngunut Kecamatan Jumantono Kabupaten Karanganyar amat menarik untuk diteliti, dimana kesuksesan yang dicapai dapat ditunjukkan dari peningkatan kinerja usaha. Kinerja usaha wirausaha wanita di bidang tanaman obat keluarga (TOGA) selain memberikan kontribusi pada peningkatan pendapatan keluarga juga dapat mendukung perekonomian di daerah Karanganyar terutama bagi perkembangan bisnis jamu. Program kemitraan petani TOGA dengan perusahaan jamu memberikan peluang bagi petani untuk meningkatkan penjualan yang selanjutnya dapat meningkatkan pendapatan keluarga.

Hasil penelitian sebelumnya mengenai faktor-faktor yang mempengaruhi kinerja usaha telah banyak dilakukan. Penelitian yang dilakukan oleh Perengki Susanto (2012); Rita Indah Mustikowati \& Irma Tysari (2014); dan Cynthia Vanessa Djodjobo \& Hendra N. Tawas (2014) menunjukkan bahwa orientasi kewirausahaan dan orientasi pasar berpengaruh signifikan terhadap kinerja usaha kecil. Penelitian yang dilakukan oleh Bayu Sumantri dkk (2013) menunjukkan bahwa kinerja usaha wirausaha wanita pada industri pangan rumahan di Bogor dapat dipengaruhi oleh karakteristik personal yang terdiri dari pendidikan, usia, pengalaman usaha, dan pelatihan. Penelitian yang dilakukan oleh Galuh Juniarto \& Siti Aminah (2013) menunjukkan bahwa kebutuhan akan prestasi berpengaruh signifikan terhadap kesuksesan entrepreneur wanita di kota Semarang.

Berdasarkan hasil temuan sebelumnya menunjukkan bahwa kinerja usaha bagi seorang entrepreneur wanita dapat dipengaruhi banyak faktor, diantaranya adalah kebutuhan berprestasi dan karakteristik personal berupa pendidikan, usia, pengalaman usaha, dan pelatihan. Sejalan dengan hasil temuan sebelumnya penelitian ini akan menganalisis pengaruh kebutuhan berprestasi dan karakteristik personal berupa pendidikan, usia, pengalaman usaha, dan pelatihan terhadap kinerja usaha wirausaha wanita pada petani Tanaman Obat Keluarga (TOGA) di wilayah Kecamatan Jumantono Kabupaten Karanganyar.

Luaran penelitian ini adalah artikel yang dipublikasikan pada JURNAL EKONOMI DAN KEWIRAUSAHAAN, Universitas Slamaet Riyadi Surakarta. 
Berdasarkan latar belakang yang penulis kemukakan diatas, maka perumusan masalah dalam penelitian ini adalah sebagai berikut :

1. Apakah kebutuhan berprestasi berpengaruh signifikan terhadap kinerja usaha wirausaha wanita pada petani Toga di Kecamatan Jumantono Kabupaten Karanganyar?

2. Apakah pendidikan berpengaruh signifikan terhadap kinerja usaha wirausaha wanita pada petani Toga di Kecamatan Jumantono Kabupaten Karanganyar?

3. Apakah usia berpengaruh signifikan terhadap kinerja usaha wirausaha wanita pada petani Toga di Kecamatan Jumantono Kabupaten Karanganyar?

4. Apakah pengalaman usaha berpengaruh signifikan terhadap kinerja usaha wirausaha wanita pada petani Toga di Kecamatan Jumantono Kabupaten Karanganyar?

5. Apakah pelatihan berpengaruh signifikan terhadap kinerja usaha wirausaha wanita pada petani Toga di Kecamatan Jumantono Kabupaten Karanganyar?

Berdasarkan pokok masalah yang telah diutarakan sebelumnya, maka tujuan dari penelitian ini adalah sebagai berikut :
1. Untuk menganalisis signifikansi pengaruh kebutuhan berprestasi terhadap kinerja usaha wirausaha wanita pada petani Toga di Kecamatan Jumantono Kabupaten Karanganyar.

2. Untuk menganalisis signifikansi pengaruh pendidikan terhadap kinerja usaha wirausaha wanita pada petani Toga di Kecamatan Jumantono Kabupaten Karanganyar.

3. Untuk menganalisis signifikansi pengaruh usia terhadap kinerja usaha wirausaha wanita pada petani Toga di Kecamatan Jumantono Kabupaten Karanganyar.

4. Untuk menganalisis signifikansi pengaruh pengalaman usaha terhadap kinerja usaha wirausaha wanita pada petani Toga di Kecamatan Jumantono Kabupaten Karanganyar.

5. Untuk menganalisis signifikansi pengaruh pelatihan terhadap kinerja usaha wirausaha wanita pada petani Toga di Kecamatan Jumantono Kabupaten Karanganyar.

Kontribusi penelitian adalah memberikan pemahaman teoritis, metodologis dan praktis tentang pengaruh kebutuhan berprestasi, pendidikan, usia, pengalaman usaha, dan pelatihan terhadap kinerja usaha 
wirausaha wanita. Penelitian ini dapat digunakan sebagai acuan dalam menetapkan kebijakan Pemerintah Daerah khususnya Pemerintah Kabupaten Karanganyar dalam pemberdayaan para petani Toga.

\section{METODE PENELITIAN}

\section{Populasi dan Sampel}

Penelitian ini mengambil

lokasi di Kabupaten Karanganyar dengan objek penelitian di Kecamatan Jumantono. Populasi dalam penelitian ini seluruh petani Tanaman Obat Keluarga (TOGA) di wilayah Kecamatan Jumantono Kabupaten Karanganyar dengan jumlah populasi sebanyak 63 petani. Penelitian ini menggunakan studi sensus, mengambil seluruh elemen yang ada pada populasi untuk digunakan sebagai responden.

\section{Definisi Operasional Variabel}

1. Kebutuhan Berprestasi adalah keinginan petani untuk mencapai keberhasilan dalam menjalankan usaha taninya. Item-item yang dijadikan dasar penilaian kinerja usaha antara lain meliputi (1) kemauan untuk terus belajar, (2) partisipasi dalam penyuluhan, (3) keinginan meningkatkan kegiatan peningkatan produksi, keikutsertaan dalam pengembangan budidaya, keterlibatan dalam pelatihan (Darmadji, 2012). Variabel ini diukur dengan skala Likert 5 poin, dengan alternatif jawaban mulai dari Sangat Setuju (5), Setuju (4), Netral (3), Tidak Setuju (2), Sangat Tidak Setuju (1).

2. Karakteristik Personal adalah karakteristik individu yang dimiliki petani dalam menjalankan usaha tani meliputi pendidikan, usia, pengalaman usaha, dan pelatihan.

a. Variabel pendidikan adalah karakteristik yang menerangkan tingkat pendidikan tertinggi petani tanaman Toga di Kecamatan Jumantono Kabupaten Karanganyar. Pendidikan dikategorisasi dari pendidikan terendah SD, SLTP, SMA, Diploma, dan Sarjana. Pengkodean untuk variabel pendidikan adalah sebagai berikut :

Kode 1 untuk pendidikan SD

Kode 2 untuk pendidikan SLTP

Kode 3 untuk pendidikan SLTA

Kode 4 untuk pendidikan Diploma (D1/D2/3)

Kode 5 untuk pendidikan Sarjana

b. Variabel usia adalah karakteristik yang menerangkan usia petani 
tanaman Toga di Kecamatan Jumantono

Kabupaten

Karanganyar. Variabel usia diukur dalam satuan tahun.

c. Variabel pengalaman usaha adalah karakteristik yang menerangkan lamanya petani di wilayah Kecamatan Jumantono Kabupaten Karanganyar dalam menjalankan usaha tani Tanaman Toga. Variabel pengalaman usaha diukur dalam satuan tahun.

d. Variabel pelatihan adalah karakteristik yang menerangkan pendidikan atau proses belajar terencana yang pernah diikuti oleh petani di wilayah Kecamatan Jumantono Kabupaten Karanganyar yang didapatkan diluar sekolah formal. Pengkodean untuk variabel pelatihan adalah sebagai berikut:

Kode 1 jika belum pernah mengikuti pelatihan

Kode 2 jika pernah mengikuti pelatihan $<25$ jam

Kode 3 jika pernah mengikuti pelatihan 25 jam - 50 jam

Kode 4 jika pernah mengikuti pelatihan $>50$ jam

\section{Kinerja Usaha}

Kinerja usaha adalah tingkat keberhasilan usaha tani Tanaman Toga yang dicapai oleh wirausaha wanita di Kecamatan Jumantono Kabupaten Karanganyar, diukur dari peningkatan penjualan, peningkatan keuntungan bersih, dan peningkatan modal (Lee \& Tsang dalam Windi Astuti \& Murwatiningsih, 2016). Pengukuran variabel kinerja usaha menggunakan skala biner, dengan alternatif jawaban Tidak (0) dan Ya (1).

Pada analisis Regresi Binary Logistic variabel dependen kinerja usaha dikategorikan kedalam 2 kategori (biner) sebagai berikut : $\mathrm{Y}=0 \quad$ : kinerja usaha yang dicapai petani diprediksi Rendah $\mathrm{Y}=1$ : kinerja usaha yang dicapai petani diprediksi Tinggi

\section{Metode Pengumpulan Data}

Penelitian ini menggunakan sumber data primer, data diperoleh dengan menyebarkan kuesioner kepada responden.

\section{Uji Instrumen Penelitian}

Pengujian validitas instrumen untuk variabel kebutuhan berprestasi dan kinerja usaha menggunakan teknik Pearson Correlation, sedangkan pengujian reliabilitas instrumen menggunakan teknik Cronbach Alpha.

Teknik Analisis Data 
Teknik analisis data menggunakan regresi binary logistic, bertujuan untuk menguji apakah odds/probabilitas kinerja usaha dapat diprediksi dengan kemampuan berprestasi, pendidikan, usia, pengalaman, dan pelatihan. Model regresi binary logistic dalam penelitian ini dinyatakan dengan persamaan sebagai berikut:

$\operatorname{Ln}(\mathrm{TL} / 1-\mathrm{TL})=\mathrm{a}+\mathrm{b}_{1} \mathrm{~KB}+\mathrm{b}_{2}$ PEND + $b_{3} U S+b_{4} P U+b_{5} P L+e$
Keterangan :

$\operatorname{Dummy}_{(K U)}=$ probabilitas kinerja usaha yang merupakan variabel binner $(0=$ Rendah dan $1=$ Tinggi)

$\mathrm{KU}=$ Kinerja Usaha

$\mathrm{KB} \quad=$ Kebutuhan berprestasi

PEND $\quad=$ Pendidikan

USIA $\quad=$ Usia

PU $\quad=$ Pengalaman usaha

PL $\quad=$ Pelatihan

e $\quad$ error

HASIL PENELITIAN

Uji Instrumen Penelitian

1. Uji Validitas

Hasil uji validitas variabel kebutuhan berprestasi disajikan seperti tabel berikut.

Tabel 1: Hasil Uji Validitas Variabel Kebutuhan Berprestasi

\begin{tabular}{cccc}
\hline Butir pernyataan & $p$ value & $\alpha$ & Kesimpulan \\
\hline KB1 & 0,000 & 0,05 & Valid \\
KB2 & 0,000 & 0,05 & Valid \\
KB3 & 0,000 & 0,05 & Valid \\
KB4 & 0,000 & 0,05 & Valid \\
KB5 & 0,000 & 0,05 & Valid \\
\hline
\end{tabular}

Sumber: Data primer diolah, 2019

Berdasarkan hasil diatas dapat diketahui bahwa semua butir pernyataan untuk variabel kebutuhan berprestasi menghasilkan $p$ value $<0,05$ berarti seluruh butir pernyataan variabel kebutuhan berprestasi valid.

Hasil uji validitas untuk variabel variabel kinerja usaha disajikan seperti tabel berikut.

Tabel 2: Hasil Uji Validitas Variabel Kinerja Usaha

\begin{tabular}{cccc}
\hline Butir pernyataan & $p$ value & $\alpha$ & Kesimpulan \\
\hline KU1 & 0,000 & 0,05 & Valid \\
\hline KU2 & 0,000 & 0,05 & Valid \\
\hline KU3 & 0,000 & 0,05 & Valid
\end{tabular}

Sumber: Data primer diolah, 2019

Berdasarkan hasil diatas dapat diketahui bahwa semua butir pernyataan untuk variabel kinerja usaha menghasilkan $p$ value $<0,05$ berarti seluruh butir pernyataan variabel kinerja usaha valid. 
2. Uji Reliabilitas

Pengujian reliabilitas instrumen untuk variable kebutuhan berprestasi dan kinerja usaha diperoleh Cronbach Alpha > 0,6 artinya semua instrumen penelitian ini dinyatakan reliabel. Olah data melalui program SPSS menyajikan hasilnya sebagai berikut.

Tabel 3: Hasil Uji Reliabilitas Instrumen

\begin{tabular}{lccc}
\hline \multicolumn{1}{c}{ Variabel } & Cronbach Alpha & Kriteria uji & Kesimpulan \\
\hline Kebutuhan berprestasi & 0,722 & 0,60 & Reliabel \\
Kinerja Usaha & 0,741 & 0,60 & Reliabel \\
\hline
\end{tabular}

Sumber : Data primer diolah, 2019

\section{Karakteristik Personal}

Responden dalam penelitian semuanya adalah wanita, yaitu ibu-ibu rumah tangga yang terlibat dalam pengelolaan budidaya tanama obat keluarga (TOGA). Berdasarkan hasil penelitian berikut ini dapat diuraikan karakteristik personal responden menurut pendidikan, usia, pengalaman usaha, dan pelatihan kewirausahaan.

Tabel 4: Karakteristik Personal

\begin{tabular}{|c|c|c|c|}
\hline Karakteristik & Keterangan & Jumlah (orang) & $\begin{array}{c}\text { Persentase } \\
(\%)\end{array}$ \\
\hline Tingkat & SD & 32 & 50,79 \\
\hline \multirow[t]{5}{*}{ Pendidikan } & SLTP & 20 & 31,75 \\
\hline & SLTA & 7 & 11,11 \\
\hline & Diploma (D1/D2/D3) & 3 & 4,76 \\
\hline & Sarjana (S1) & 1 & 1,59 \\
\hline & Total & 63 & 100 \\
\hline \multirow[t]{4}{*}{ Usia } & Kurang dari 25 tahun & 11 & 17,46 \\
\hline & $25-45$ tahun & 45 & 71,43 \\
\hline & Lebih dari 45 tahun & 7 & 11,11 \\
\hline & Total & 63 & 100 \\
\hline \multirow{5}{*}{$\begin{array}{l}\text { Pengalaman } \\
\text { usaha }\end{array}$} & Kurang dari 10 tahun & 14 & 22,22 \\
\hline & $10-15$ tahun & 19 & 30,16 \\
\hline & $16-20$ tahun & 23 & 36,51 \\
\hline & Lebih dari 20 tahun & 7 & 11,11 \\
\hline & Total & 63 & 100 \\
\hline \multirow[t]{5}{*}{$\begin{array}{l}\text { Pelatihan } \\
\text { Kewirausahaan }\end{array}$} & $\begin{array}{l}\text { Belum pernah mengikuti } \\
\text { pelatihan }\end{array}$ & 13 & 20,63 \\
\hline & $\begin{array}{l}\text { Pernah mengikutı pelatihan < } \\
25 \text { jam }\end{array}$ & 37 & 58,73 \\
\hline & $\begin{array}{l}\text { Pernah mengikuti pelatihan } \\
25-50 \text { jam } \\
\text { Pernah mengikuti pelatihan }>\end{array}$ & 10 & 15,87 \\
\hline & 50 jam & 3 & 4,76 \\
\hline & Total & 63 & 100 \\
\hline
\end{tabular}

Sumber : Data primer diolah, 2019 


\section{Pengujian Hipotesis}

Alat analisis yang digunakan dalam penelitian ini adalah model regresi binary logistic bertujuan untuk menguji apakah odds/probabilitas kinerja usaha dapat diprediksi dengan kemampuan berprestasi, pendidikan, usia, pengalaman, dan pelatihan.

1. Uji Ketepatan Model

Untuk menilai ketepatan model regresi binary logistic dalam penelitian ini dianalisis dengan Hosmer and Lemeshow Test.

Tabel 5: Hosmer and Lemeshow Test

\begin{tabular}{lrrrr}
\hline Step & Chi-square & df & \multicolumn{2}{c}{ Sig. } \\
\hline 1 & 13,365 & 8 & 0,100 \\
\hline
\end{tabular}

Sumber : Data primer diolah, 2019

Hasil Hosmer and Lemeshow Test seperti terlihat pada Tabel 6 diperoleh nilai Chi-Square $=13,365$ dengan tingkat signifikansi sebesar 0,100. Angka tersebut lebih besar dari 0,05 maka Ho diterima. Hal ini berarti model regresi binary logistic dengan variabel dependen kinerja usaha adalah fit atau sesuai dengan data sehingga layak dipakai untuk analisis selanjutnya.

2. Analisis Regresi Binary Logistic

Berdasarkan analisis regresi binary logistic diperoleh hasil sebagai berikut,

Tabel 6: Hasil Analisis Regresi Binary Logistic

\begin{tabular}{llrrrrr}
\hline & & \multicolumn{2}{c}{ S.E. } & Wald & df & \multicolumn{2}{c}{ Sig. } \\
\hline Step & KB & 0,267 & 0,130 & 4,232 & 1 & 0,040 \\
$1^{\text {a }}$ & PEND & 0,132 & 0,547 & 0,059 & 1 & 0,809 \\
& USIA & 0,000 & 0,042 & 0,000 & 1 & 0,993 \\
& PU & 0,199 & 0,083 & 5,726 & 1 & 0,017 \\
& PL & 0,534 & 0,633 & 0,712 & 1 & 0,399 \\
& Constant & $-8,194$ & 3,063 & 7,158 & 1 & 0,007 \\
\hline
\end{tabular}

a. Variable(s) entered on step 1: KB, PEND, USIA, PU, PL.

Sumber : Data primer diolah, 2019

Hasil dari pengujian model regresi binary logistic dengan variabel dependen kinerja usaha diperoleh persamaan sebagai berikut.

$$
\begin{aligned}
& \text { KU }=-8,194+0,267 \mathbf{K B}+ \\
& 0,132 \text { PEND }+0,000 \text { USIA }+ \\
& 0,199 \text { PU }+0,534 \mathbf{P L}
\end{aligned}
$$

Persamaan diatas dapat ditafsirkan bahwa kelima prediktor yaitu kebutuhan berprestasi, pendidikan, usia, pengalaman usaha, dan pelatihan kewirausahaan berpengaruh positif terhadap kinerja usaha wirausaha wanita pada petani Tanaman Obat Keluarga (TOGA) di Kecamatan Jumantono Kabupaten Karanganyar.

3. Uji Signifikansi Koefisien Regresi 
Uji signifikansi koefisien regresi untuk menguji signifikansi pengaruh masing-masing variabel independen terhadap variabel dependen. Pengujian ini dilakukan dengan melihat nilai signifikansi Wald yang dilaporkan pada print out SPSS. Berdasarkan hasil analisis regresi seperti Tabel 6 berikut ini diuraikan hasil pengujian masing-masing variabel.

a. Uji signifikansi pengaruh kebutuhan berprestasi terhadap kinerja usaha

Dari hasil analisis regresi binary logistic diketahui bahwa variabel kebutuhan berprestasi menghasilkan nilai signifikansi Wald sebesar 0,040 yang lebih kecil dari 0,05 berarti $\mathrm{H} 0$ ditolak dan $\mathrm{H} 1$ diterima. Dengan demikian kebutuhan berprestasi berpengaruh signifikan terhadap kinerja usaha wirausaha wanita pada petani Toga di Kecamatan Jumantono Kabupaten Karanganyar.

b. Uji signifikansi pengaruh pendidikan terhadap kinerja usaha

Dari hasil analisis regresi binary logistic diketahui bahwa variabel pendidikan menghasilkan nilai signifikansi Wald sebesar 0,809 yang lebih besar dari 0,05 berarti $\mathrm{H} 0$ diterima dan H2 ditolak. Dengan demikian pendidikan tidak berpengaruh signifikan terhadap kinerja usaha wirausaha wanita pada petani Toga di Kecamatan Jumantono Kabupaten Karanganyar.

c. Uji signifikansi pengaruh usia terhadap kinerja usaha

Dari hasil analisis regresi binary logistic diketahui bahwa variabel usia menghasilkan nilai signifikansi Wald sebesar 0,993 yang lebih besar dari 0,05 berarti H0 diterima dan H3 ditolak. Dengan demikian usia tidak berpengaruh signifikan terhadap kinerja usaha wirausaha wanita pada petani Toga di Kecamatan Jumantono Kabupaten Karanganyar.

d. Uji signifikansi pengaruh pengalaman usaha terhadap kinerja usaha

Dari hasil analisis regresi binary logistic diketahui bahwa variabel pengalaman usaha menghasilkan nilai signifikansi Wald sebesar 0,017 yang lebih kecil dari 
0,05 berarti $\mathrm{H} 0$ ditolak dan $\mathrm{H} 4$ diterima. Dengan demikian pengalaman usaha berpengaruh signifikan terhadap kinerja usaha wirausaha wanita pada petani Toga di Kecamatan Jumantono Kabupaten Karanganyar.

e. Uji signifikansi pengaruh pelatihan kewirausahaan terhadap kinerja usaha

Dari hasil analisis regresi binary logistic diketahui bahwa variabel pelatihan kewirausahaan menghasilkan nilai signifikansi Wald sebesar 0,399 yang lebih besar dari 0,05 berarti $\mathrm{H} 0$ diterima dan H5 ditolak. Dengan demikian pelatihan kewirausahaan tidak berpengaruh signifikan terhadap kinerja usaha wirausaha wanita pada petani Toga di Kecamatan Jumantono Kabupaten Karanganyar.

\section{PEMBAHASAN}

1. Pengaruh kebutuhan berprestasi terhadap kinerja usaha

Temuan dari hasil penelitian ini, kebutuhan berprestasi berpengaruh signifikan terhadap kinerja usaha wirausaha wanita pada petani Toga di Kecamatan Jumantono Kabupaten Karanganyar. Tand akoefisien regresi positif menunjukkan bahwa semakin tinggi kebutuhan berprestasi, maka kinerja usaha akan semakin tinggi. Hal ini didukung dengan nilai signifikansi Wald sebesar 0,040 yang lebih kecil dari $\alpha=0,05$. Dengan demikian hipotesis 1 diterima atau terbukti kebenarannya.

Kebutuhan berprestasi dalam penelitian ini merupakan motivasi berwirausaha yang datangnya dari dalam diri wirausaha TOGA yaitu keinginan petani untuk mencapai keberhasilan dalam menjalankan usaha taninya. Tinggi rendahnya kebutuhan berprestasi dari wirausaha dapat dilihat dari kemauan untuk terus belajar, tingkat partisipasi dalam penyuluhan, keinginan meningkatkan kegiatan peningkatan produksi, keikutsertaan dalam pengembangan budidaya, danketerlibatan dalam pelatihan. Temuan ini mendukung penelitian sebelumnya yang dilakukan oleh Galuh Juniarto \& Siti Aminah (2013) yang menyatakan kebutuhan akan prestasi 
berpengaruh signifikan terhadap kesuksesan entrepreneur wanita di Kota Semarang. Para entrepreneur wanita di Kota Semarang yang memiliki kebutuhan akan prestasi tinggi akan semakin mudah mencapai kesuksesan usaha, karena mereka menunjukkan usaha keras, memiliki semangat juang yang tinggi, dan berani mengambil risiko terhadap usaha yang dikelola.

2. Pengaruh pendidikan terhadap kinerja usaha

Temuan dari hasil penelitian ini, pendidikan tidak berpengaruh signifikan terhadap kinerja usaha wirausaha wanita pada petani Toga di Kecamatan Jumantono Kabupaten Karanganyar, ditunjukkan dengan nilai signifikansi Wald sebesar 0,809 yang lebih besar dari $\alpha=$ 0,05 . Dengan demikian hipotesis 2 ditolak. Tanda koefisien regresi pendidikan adalah positif, menunjukkan bahwa semakin tinggi pendidikan, maka kinerja usaha akan semakin tinggi. Hasil penelitian ini tidak sejalan dengan penelitian sebelumnya yang dilakukan oleh Bayu Sumantri dkk (2013) yang menyatakan bahwa karakteristik personal pendidikan berpengaruh signifikan terhadap kinerja usaha wirausaha wanita pada industri pangan rumahan di Bogor.

Menurut Dwijayanthi dkk (2013) tingkat pendidikan yang lebih tinggi akan memudahkan seseorang atau masyarakat untuk menyerap informasi dan mengimplementasikannya. Oleh karenanya untuk meningkatkan kemampuan seseorang, diperlukan pendidikan sehingga dengan pendidikan yang semakin tinggi maka pengambilan keputusan akan menjadi lebih tepat dan akurat.

Berdasarkan hasil penelitian ini pendidikan wirausaha wanita pada petani Toga di Kecamatan Jumantono Kabupaten Karanganyar merupakan karakteristik yang menerangkan tingkat pendidikan tertinggi dari para petani mulai dari pendidikan terendah $\mathrm{SD}$, SLTP, SMA, Diploma, dan Sarjana. Karakteristik personal responden berdasarkan tingkat pendidikan dalam penelitian ini mayoritas adalah Sekolah Dasar $(50,79 \%)$ dan SLTP $(31,75 \%)$ Dalam kenyataannya tingkat pendidikan petani Toga yang mayoritas berpendidikan rendah, mampu menjalankan kegiatan usahanya dengan baik bahkan 
beberapa ada yang mencapai sukses dalam budidaya Toga. Hal ini disebabkan karena kinerja usaha dibidang budidaya Toga tidak sepenuhnya dipengaruhi oleh tinggi pendidikan, namun para petani Toga yang berhasil karena mereka telah memiliki pengalaman dalam mengelola usahanya.

3. Usia pendidikan terhadap kinerja usaha

Temuan dari $r$ hasil
penelitian ini, usia tidak
berpengaruh signifikan terhadap
kinerja usaha wirausaha wanita
pada petani Toga di Kecamatan
Jumantono

Karanganyar, ditunjukkan dengan nilai signifikansi Wald sebesar 0,993 yang lebih besar dari $\alpha=$ 0,05 . Dengan demikian hipotesis 3 ditolak. Hasil penelitian ini tidak sejalan dengan penelitian sebelumnya yang dilakukan oleh Bayu Sumantri dkk (2013) yang menyatakan bahwa karakteristik personal usia berpengaruh signifikan terhadap kinerja usaha wirausaha wanita pada industri pangan rumahan di Bogor.

Perbedaan usia bagi pekerja yang lebih muda lebih dipengaruhi oleh sikap, sebaliknya pekerja yang lebih tua lebih dipengaruhi oleh norma subjektif dan kontrol perilaku (Morris dan Venkatesh, 2000). Umur berpengaruh negatif terhadap keahlian individu, jika umur meningkat maka keahlian individu cenderung menurun (Putu Widya Anjani \& Ni Gusti Putu Wirawati (2018).

Usia responden dalam penelitian ini merupakan karakteristik yang menerangkan usia petani tanaman Toga di Kecamatan Jumantono Kabupaten Karanganyar. Tingkat usia responden bersifat heterogen, dimana $17,46 \%$ berusia kurang dari 25 tahun, $71,43 \%$ berusia antara 25 - 45 tahun dan berusia yang lebih dari 45 tahun 11,11\%. Dalam kenyataannya usia petani Toga di di Kecamatan Jumantono Karanganyar tidak begitu berpengaruh terhadap kinerja usaha. Hal ini disebabkan, dengan tingkat usia yang berbeda namun mereka memiliki motivasi yang sama yaitu menjadi wirausaha sukses di bidang pertanian Toga, sehingga perbedaan usia bagi petani Toga tidak memberikan pengaruh yang berarti pada kinerja usaha.

4. Pengalaman usaha terhadap kinerja usaha

Pengalaman usaha dalam penelitian ini adalah karakteristik 
yang menerangkan lamanya petani di wilayah Kecamatan Jumantono Kabupaten Karanganyar dalam menjalankan usaha tani Tanaman Toga. Temuan dari hasil penelitian ini, pengalaman usaha berpengaruh signifikan terhadap kinerja usaha wirausaha wanita pada petani Toga di Kecamatan Jumantono Kabupaten Karanganyar, ditunjukkan dengan nilai signifikansi Wald sebesar 0,017 yang lebih kecil dari $\alpha=0,05$. Dengan demikian hipotesis 4 diterima. Semakin tinggi pengalaman usaha maka kinerja usaha akan semakin tinggi. Hasil penelitian ini mendukung penelitian sebelumnya yang dilakukan oleh Bayu Sumantri dkk (2013) yang menyatakan bahwa karakteristik personal pengalaman usaha berpengaruh signifikan terhadap kinerja usaha wirausaha wanita pada industri pangan rumahan di Bogor.

Temuan ini sejalan dengan pendapat Tiksnayana Vipraprastha \& Maria Ratna Sari (2016) bahwa pengalaman adalah suatu faktor untuk menilai seberapa lama seseorang mengetahui atau bertukar pengetahuan dengan orang lain untuk bisa melaksanakan pekerjaannya secara efektif. Lebih lanjut Widyantari dkk (2016) menyatakan bahwa terdapat pengaruh yang positif pengalaman usaha terhadap kinerja individu. Artinya, pengalaman kerja seseorang sangat mempengaruhi karakter dalam bekerja karena semakin lama seseorang bekerja maka akan semakin baik kinerja seseorang.

5. Pelatihan kewirausahaan terhadap kinerja usaha

Pelatihan kewirausahaan dalam penelitian ini merupakan karakteristik yang menerangkan pendidikan atau proses belajar terencana yang pernah diikuti oleh petani Toga di wilayah Kecamatan Jumantono Kabupaten Karanganyar yang didapatkan diluar sekolah formal. Valerio et,al. (2014) menyatakan bahwa pendidikan dan pelatihan kewirausahaan turut berperan dalam menumbuhkan semangat kewirausahaan. Pendidikan dan pelatihan kewirausahaan merupakan sistem pendidikan dan pelatihan yang menggabungkan kreativitas dan kemampuan manajerial kewirausahaan ke dalam metodologi pengajaran, pola pikir dan keterampilan yang terkait dengan seni kewirausahaan.

Dalam prakteknya, program pendidikan dan pelatihan kewirausahaan/ Entrepreneurship Education and Training (EET) 
program, diklasifikasikan menjadi dua kategori program yaitu education program (program pendidikan) dan training program (program pelatihan). Keduanya dibedakan dari tujuan dan hasil dari masing-masing program. Academic Entrepreneurship Education (EE) Program cenderung fokus untuk membangun pengetahuan dan keterampilan tentang kewirausahaan, termasuk tujuan kewirausahaan. Entrepreurship Training (ET) Program cenderung fokus untuk membangun pengetahuan dan keterampilan secara eksplisit dalam persiapan untuk memulai suatu usaha. Keduanya program ini juga dibedakan dari target program tersebut, dimana program pendidikan kewirausahaan ditargetkan pada siswa pendidikan menengah atas dan mahasiswa, sedangkan program pelatihan kewirausahaan ditargetkan pada pengusaha-pengusaha berpotensi dan pengusaha yang sedang berlatih (Valerio, et.al, 2014).

Temuan dari hasil penelitian ini, pelatihan kewirausahaan tidak berpengaruh signifikan terhadap kinerja usaha wirausaha wanita pada petani Toga di Kecamatan Jumantono Kabupaten Karanganyar, ditunjukkan dengan nilai signifikansi Wald sebesar 0,399 yang lebih besar dari $\alpha=0,05$. Dengan demikian hipotesis 5 ditolak. Hal ini dapat disebabkan karena kinerja dan keberhasilan usaha petani Toga di Kecamatan Jumantono Kabupaten Karanganyar tidak sepenuhnya dipengaruhi oleh pelatihan yang diikuti. Dalam kenyataanya para petani yang kurang terlibat atau bahkan belum pernah mengikuti pelatihan kewirausahaan mampu mengelola usahanya dengan baik, hal ini dikarenakan mereka telah memiliki pengalaman yang memadai dibidang budidaya Toga. Hasil penelitian ini tidak sejalan dengan penelitian sebelumnya yang dilakukan oleh Bayu Sumantri dkk (2013) yang menyatakan bahwa karakteristik personal pengalaman usaha berpengaruh signifikan terhadap kinerja usaha wirausaha wanita pada industri pangan rumahan di Bogor.

\section{KESIMPULAN DAN}

\section{KETERBATASAN}

\section{Kesimpulan}

Berdasarkan hasil analisis regresi binary logistic, menunjukkan bahwa dari lima prediktor yang berpengaruh positif terhadap kinerja usaha wirausaha wanita pada petani Toga di Kecamatan Jumantono Kabupaten Karanganyar adalah kebutuhan berprestasi dan 
pengalaman usaha, sedangkan variabel pendidikan, usia, dan pelatihan kewirausahaan tidak berpengaruh signifikan terhadap kinerja usaha. Berdasarkan hasil penelitian ini odds/probabilitas kinerja usaha wirausaha wanita pada petani Toga di Kecamatan Jumantono Kabupaten Karanganyar dapat diprediksi dengan kebutuhan berprestasi dan pengalaman usaha. Implikasi dari temuan ini, untuk mencapai kinerja usaha yang tinggi para petani Toga di Kecamatan Jumantono Kabupaten Karanganyar

\section{DAFTAR PUSTAKA}

Amirullah dan Imam Hardjianto, 2005, Pengantar Bisnis, Graha Ilmu, Yogyakarta.

Bayu Sumantri, Anna Fariyanti, dan Ratna Winandi, 2013, "FaktorFaktor yang Berpengaruh terhadap Kinerja Usaha Wirausaha Wanita: Suatu Studi pada Industri Pangan Rumahan di Bogor", Jurnal Manajemen Teknologi, Vol. 12 (3), Hal. 252-277.

Cynthia Vanessa Djodjobo \& Hendra N. Tawas, 2014, "Pengaruh Orientasi Kewirausahaan, Inovasi Produk, dan Keunggulan Bersaing terhadap Kinerja Pemasaran Usaha Nasi Kuning di Kota Manado", Jurnal EMBA, Vol. 2 (3), November. Hal. 1214-1224.

Daft, Richard L, 2010, Era Baru Manajemen, Salemba, Jakarta. perlu meningkatkan kebutuhan berprestasi dan pengalaman usaha.

\section{Keterbatasan Penelitian}

Sampel penelitian ini hanya terbatas pada wirausaha wanita pada petani Toga di Kecamatan Jumantono Kabupaten Karanganyar saja, sehingga hasil penelitian tidak bisa digeneralisir. Dalam penelitian ini, data yang dikumpulkan adalah data primer yang dikumpulkan melalui kuesioner berdasarkan persepsi responden, tidak melakukan survei langsung, sehingga ada kemungkinan mengandung kelemahan mengenai validitas internal.

Darmadji, 2012, "Analysis Of Farmers EntrepreneurshipAnalisis Kewirausahaan Petani", Jurnal AGRIKA, Vol. 6 (1), Hal. 48-64.

Diah Nurdiwaty, Erna Puspita, Amin Tohari, Dian Kusumaningtyas, Mar'atus Solikah, Sigit Puji Winarko, dan Faisol, 2017, "Pemberdayaan Wanita Melalui Tanaman Toga Untuk Membantu Meningkatkan Pendapatan Keluarga", Jurnal ABDINUS, Vol. 1 (1), Hal. 2027.

Dwijayanthi, Diah Maha dan I.B. Dharmadiaksa. 2013. "Pengaruh Insentif, Tingkat Pendidikan, Pelatihan dan Pengalaman Kerja pada Kinerja Individu Pengguna Sistem Informasi Akuntansi SKPD Dispenda Kota Denpasar”. Denpasar : E-Jurnal 
Akuntansi Universitas Udayana, Vol. 4 (2), Hal. 332-344.

Galuh Juniarto dan Siti Aminah, 2013, "Pengaruh Kebutuhan Akan Prestasi, Kebutuhan Afiliasi, Kebutuhan Dominasi dan Kebutuhan Otonomi terhadap Kesuksesan Entrepreneur Wanita Di Kota Semarang", Jurnal Ilmiah Dinamika Ekonomi dan Bisnis, Vol. 1 (2), Hal. 48-59.

Morris, Michael G. dan Viswanath Venkatesh. 2000. "Age Differences in Technology Adoption Decisions : Implications for A Changing Work Force". Personnel Psychology: Vol. 53, Issue 2.

Perengki Susanto, 2012, "Pengaruh Orientasi Pasar pada Kinerja Perusahaan Kecil", Jurnal Kajian Manajemen Bisnis, Vol 1 (2), September, Hal. 45-60.

Putu Widya Anjani dan Ni Gusti Putu Wirawati. 2018. "Pengaruh Usia, Pengalaman Kerja, Tingkat Pendidikan, dan Kompleksitas Tugas terhadap Efektivitas Pengguna Sistem Informasi Akuntansi”. E-Jurnal Akuntansi Universitas Udayana, Vol.22 (3), Hal. 2430-2457.

Rita Indah Mustikowati \& Irma Tysari, 2014, "Orientasi Kewirausahaan, Inovasi, dan Strategi Bisnis untuk Meningkatkan Kinerja Perusahaan (Studi pada UKM Sentra Kabupaten Malang)", Jurnal: MODERNISASI, Vol. 10 (1), Februari, Hal. 23-37.
Tiksnayana Vipraprastha dan Maria Ratna Sari. 2016. Pengaruh Faktor-Faktor Kinerja Individual Karyawan Terhadap Efektivitas Penggunaan Sistem Informasi Akuntansi. Denpasar : E-Jurnal Akuntansi Universitas Udayana, Vol. 15 (3), Hal. 1826-1855.

Valerio, A., Parton, B., and Robb, A. 2014.

Entrepreneurship education and training program around the world: Dimenssion for success. The World Bank, Washington D.C.

Widyantari, Ni Wayan Lisna dan I Made Sadha Suardikha. 2016.

Pengaruh Pelatihan dan Pendidikan, Pengalaman Kerja dan Partisipasi Manajemen pada Efektivitas Penggunaan Sistem Informasi Akuntansi. Denpasar : Ejurnal Akuntansi Universitas Udayana Vol. 17 (2). Hal. 15461574.

Windi Astuti dan Murwatiningsih, 2016, "Pengaruh Kemampuan Manajemen dan Karakteristik Usaha terhadap Kinerja Usaha UKM Olahan Produk Salak di Kabupaten Banjarne:

Management Analysis Jo Vol. 5 (2), Hal. 123-127.

Online:

http://www.karanganyarkab.go.id/201 41128/toga-desa-ngunut-dinilaitim-pkk-provinsi-jawa-tengah/ Toga Desa Ngunut Dinilai Tim PKK Provinsi Jawa Tengah, Diakses tanggal 28 November 2014,10:19 WIB. Diunduh tanggal 20 Januari 2019, 19.15 WIB. 